\title{
Comic Learning Media "Three Friends" in the Akidah Akhlak (Moral Creed) Subject
}

\author{
Awal Kurnia Putra Nasution \\ IAIN Takengon, Aceh Tengah, Aceh \\ Email: awalkpn@gmail.com
}

Rina Rahmadani

Email: rina.rina9080@gmail.com

\section{A R T I C L E I N F O \\ Article history: \\ 1 Maret 2020 Received in revised form \\ 30 Maret 2020 \\ Accepted 11 April 2020 \\ Available online 15 Mei 2020 \\ Kata Kunci: \\ Pengembangan Media \\ Komik, Akidah Akhlak}

Media Development,

comic, Moral

\section{Keywords:}

\begin{abstract}
A B S T R A K
Tujuan penelitian ini adalah untuk menciptakan media pembelajaran komik yang valid dan praktis pada mata pelajaran akidah akhlak. Jenis penelitian ini yaitu Research and Development dengan menggunakan model pengembangan Borg \& Gall yang terdiri dari 10 tahapan. Teknik analisis data yang digunakan dalam penelitian ini yaitu teknik analisis deskriptif kuantitatif. Instrumen yang digunakan untuk mengumpulkan data pada pengembangan media komik Akidah Akhlak ini yaitu angket atau kuesioner dengan subjek uji coba dalam penelitian ini yaitu ahli media, ahli materi, guru dan siswa kelas VII MTs. Berdasarkan validasi ahli materi dan ahli media, dapat diketahui hasil validasi ahli materi dengan perolehan nilai presentase sebesar $81 \%$ atau sangat layak dan hasil validasi ahli media dengan perolehan nilai presentase sebesar $94,2 \%$ atau sangat layak. Hasil ujicoba dengan guru mata pelajaran Akidah Akhlak kelas VII sebagai ahli praktisi memperoleh nilai presentase sebesar $97 \%$ atau sangat layak dan hasil ujicoba terhadap 10 responden dan perolehan nilai presentase secara umum 87,6 $\%$ atau sangat baik. Secara keseluruhan menunjukkan bahwa media komik sangat layak digunakan sebagai media pembelajaran. Implikasi dari penelitian ini yaitu
\end{abstract} adanya media pembelajaran komik yang dapat digunakan oleh guru saat mengajar, sehingga pilihan media pembelajaran semakin bervariasi, yang pada akhirnya kualitas pembelajaran semakin baik.

\section{A B S T R A C T}

The purpose of the study was to create a valid and practical learning media comic on moral subject. The type of this research was Research and Development by using the Borg \& Gall development model which was consisted of 10 steps. The data analysis technique used in this study was a quantitative descriptive analysis. The instrument used to collect data on the development of the moral comic media was a questionnaire and the trial subjects in this research were media experts, material experts, teachers and the seventh-grade students of MTs (Islamic Junior High School). Based on the validation of material experts and media experts, it showed that the results of the validation of material experts with a percentage value of $81 \%$ or very feasible and the results of the validation of media experts with a percentage value of $94.2 \%$ or very feasible. The results of trial subjects on the seventh-grade teachers as an expert practitioner got a percentage value of $97 \%$ or very feasible and the results of the trial on 10 respondents got the general percentage value of $87.6 \%$ or very good. Overall, it showed that comic media was very suitable to be used as learning media. The implication of this research was the existence of comic learning media that could be used by teachers while teaching so that the choice of learning media was varied and the learning quality got better.

\section{Introduction}

The problems faced in the learning process at this time are student learning outcomes that are not in line with expectations of the planned program. Many factors cause this to happen both in the learning process and learning source. The learning process is caused by the inability of the teacher to innovate learning in other words the teacher is still transferring knowledge instead of transforming learning in the learning process. We know that learning is a process of interaction between students and learning resources programmed by the teacher. In the learning process, it is not the teacher who learns but the students. It is in line with Surya in Abdul (2013) states that learning is a process done by students to experience a change in behavior from interacting with learning resources. Besides the fact that the learning process is still low, the low learning outcomes are also caused by the lack of learning resources used by teachers. Learning resources are books, media, or other sources. This problem is not only experienced by one teacher or one school but almost every school experience the same thing. This problem is supported by the results of a study conducted at MTs Negeri (Islamic Junior High Public School) 1 Takengon.

MTs Negeri 1 Takengon is the most favorite MTs school in Central Aceh district, it does not have learning media that can be categorized as good. Some subjects did not have specific media or even had not been touched by the media, one of the subjects was Akidah Akhlak (Moral Creed) subject where teaching and learning activities were more dominantly focused on what was said by the teacher and rely more on strategy, 
whereas if it concerns to the objectives of Akidah Akhlak in increasing students' faith and devotion to Almighty God, it was very unfortunate to have lack quality of learning. The value of learning outcomes of Akidah Akhlak subject was also not in the satisfying category, it was caused by the lack of creative students in the learning process. This statement is in line with the opinion of Sun \& Cheng (2007) that the lack of instructional media will affect the lack of student interest and attention in learning. If this problem is handled soon, it will affect students' abilities both cognitive abilities, attitudes, and skills, which will indirectly affect the social life experience. From this explanation, it can be said that the media is considered as an important aspect.

Media is one component of learning that has benefits in the learning process (Sudjana, 2017). Learning media are all things that can be used to deliver a message from the sender to the recipient to stimulate students' thoughts, feelings, concerns, and interests, as well as the learning process, occurs Media in learning can lead to further curiosity to encourage students to learn actively and independently (Rusman, 2013). Meanwhile, Daryanto (2016) states that the use of media can increase the efficiency of the learning process because it assists the students to learn independently, not limited in time. So from the explanation above, the media has an important function. Arsyad (2011) Arsyad (2011) states that learning media specifically has several functions and roles, firstly learning media has the function and role of capturing a particular object or event, learning media can manipulate the situation at a particular event or object, thirdly learning media can increase student motivation and learning enthusiasm to focus more on learning material. The next function of learning media is to overcome the limitations of student experience as well as classroom boundaries and can clarify very weak sounds. After seeing how the benefits and functions of the learning media, it is clear that the existence of the media in the learning component is very important to improve the quality of the teaching and learning process, which is said to be a quality learning process if it can achieve the expected goals. Many types of media exist, one of which is comic media.

Comics are popular with adolescents because of their humorous, narrative, and visual image features, this is the strong point of comic media (Lin \& Lin, 2016). Comics are a form of reading in which students do not need to be persuaded and need for guidance from the teacher, besides comics also have function as a bridge to foster a desire to read (Rohani, 2014). Comics are a form of reading in which students read without being persuaded and through the guidance of the teacher, comics can foster the interest in (Rohani, 2014). Meanwhiel, Hidayah and Rifky (2017) state that comics are one of the learning media that activates students' seriousness in the learning process because it entertains and makes students read comics comparing to their textbooks. Comic is a cartoon that uses a character to tell an illustrated and designed story for entertaining. Modern comics are developed from comic strips in magazines or newspapers that contain interesting, funny stories packing in such a way, then along with comics development, comics are no longer made on strips and do not contain humorous stories but more broadly into action themes, science fiction, and other themes, so that readers are no longer limited to children but shifted to adolescents and adults (Koendoro, 2007: 41-47). Thus, from the description, it can be said that comic is one of the media that has special characteristics to encourage students in reading because the appearance and storyline are made interesting. This statement made several people interested in developing comic media in the learning process.

A study conducted by Fahyuni (Eni Fariyatul, Imam Fauji, 2017), this study produced comic as a learning medium and assessed whether the comic was suitable to be applied. There is little difference comparing to the present study, namely the decision at the school level. A study conducted by Utariyati (Ismi Fatimus Zahro Utariyati, 2015), this study produced comic as a learning medium that was suitable for the learning process. This is the same as what was done by the researcher, there were only differences in the comic material that would be developed. A study conducted by Ntubuo (Ntobuo, Arbie, \& Amali, 2018), showed the result of a study where the developed gravity comics were valid and can increase students' responses to learning. Another study conducted by Yulian (2018), The results showed that teaching materials in the form of comics were appropriately and effectively were used in the tenth grade students of vocational students in West Bandung. A study conducted by Sari et al., (Sari, Ratnaningtyas, Wilujeng, Jumadi, \& Kuswanto, 2019), The results showed that the application of Android comic media in thermodynamic experiments can map the process skills of high school science. Based on the result of the study above, it can be concluded that comics can improve the process and learning outcomes.

Based on the explanation above, the researcher tried to develop one of the graphic media, comic media as an alternative teacher in choosing learning media. Another goal was the expectation of student learning outcomes. It was expected to improve with the presence of comics specifically created in the subject of the Akidah Akhlah. Most people assume that comics are simple reading with stories that are only consumed for pleasure and have no value. Negative assumptions can certainly be changed by the use of comics as one of the appropriate media in interesting learning.

Based on the description above, the researchers developed one of the graphic media, namely comic media as a teacher alternative in choosing learning media. Many people assume a comic as a simple reading with a story that is used for fun without having a value. This unfavorable assumption can be changed by utilizing 
comics as a fun and useful learning media. This study aimed at developing a valid and practical comic media for Akidah Akhlak learning on Akidah Islam (Islamic Creed) in the seventh grade of MTs Negeri 1 Takengon.

\section{Method}

Research and Development are research methods that are used to produce certain products and test the effectiveness of products. According to Gall, Gall, and Borg in the book Educational Research: An Introduction, an educational development models in industries that use research findings in systematically designing these models on the field, are evaluated, improved to obtain specific criteria about effectiveness, quality, or the same standard (Sugiyono, 2015). According to Gay, Mills, and Airasian, in the field of education, the main purpose of educational research and development is not used to formulate or test theories, but it is used to develop an effective product at school (Emzir, 2013). The developed product in this study was in the form of comic media on Akidah Akhlak subject on topic Akidah Islam in the seventh grade of MTs Negeri 1 Takengon.

The development procedure or research design used in this study was adapted from the Borg and Gall development model. According to Sugiyono (2015), the research and development steps include 10 steps with the following chart:

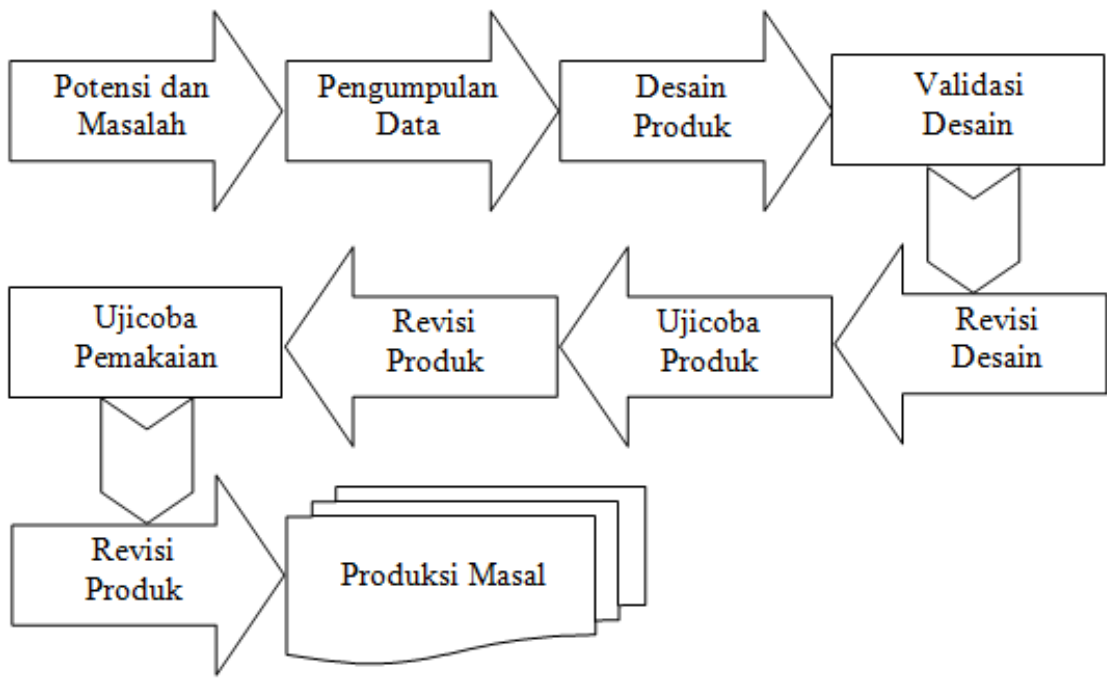

Figure 1

The Steps of Research and Development (R \& D) Model

The details of the steps of the Research and Development (R \& D) model, namely: First, the potential and problems. All research departs from the potential or the raised problem. Potential or problem is something that has value after utilization. The problem is the deviation between what is expected and what happens. While the problem in this study was the limited on Akidah Akhlak subject on topic Akidah Islam in the seventh grade of MTs Negeri 1 Takengon and the existing media had not been maximized to produce intended learning objectives. Second, data collection. After the potential problems are identified, information is carried out. The collection of information is very important to know the needs of the user community for products to be developed through research and development. In this study, the information collection was done by observation and interview both teachers and students in school. Third, product design. Based on the results of the needs analysis, the next step of development research is to design the product to be developed. In this study, researchers designed a comic media that was developed for the learning of Akidah Akhlak subject on topic Akidah Islam in the seventh grade of MTs Negeri 1 Takengon. Fourth, design validation. The next step is to validate the design. Design validation is the process of evaluating product design which is done by giving an assessment based on rational thinking, without field trials. Product validation is done by asking several experts in their fields to evaluate the product design that has been made. In this study, validation was assessed by two experts, namely material expert and media expert. Fifth, design improvements. After the product design has been validated through expert judgment, the researcher makes revisions to the product design based on expert input. Sixth, product trials. After revising the product design, the next step of research and development is to test the product. A trial is conducted to determine the effectiveness of the developed product. The trial was conducted in a limited group. Seventh, product revision. Product revision needs to be done for several reasons, namely: trials are still limited in nature, so it does not reflect the actual situation and conditions, weaknesses, and shortcomings are found in the trial of the developed products. Data for revising products can be filtered through product users 
or targeted products. Eight, trial use. After the revision is made, a trial of using the product is developed. Trials are conducted on a broader group to find out the effectiveness of the developed product and obtain input to make a final product revision. Ninth, product revision. After testing the product in a wider group, the final stage of product revision is conducted based on the obtained input. The last, mass production. This stage is the final stage of research and development. In the field of education, the mass production of developed products is a choice that has implications for wider use. The questionnaire instrument was applied to collect data on the development of the Akidah Akhlak comic media. A quantitative descriptive analysis technique was used to analyze the data in this study. Data analysis was performed to see the value of each aspect in the questionnaire. Data analysis included media feasibility data from media experts and material experts, responses provided by students as test subjects, and teachers as practitioners.

\section{Result and Discussion}

Result of the study

A developed comic media of Akidah Akhlak in this study applied a modification and development model of Borg \& Gall which consists of 10 stages, namely problem identification, information collection, product design, design validation, product revision, product testing, product revision, product trial, product revision, and mass production. The steps in research and development of the Akidah Akhlak comic media are explained as follows.

1. Identification of Problems, based on observations made by the researcher in the learning process on Akidah Akhlak subject in the seventh grade of MTs Negeri 1 Takengon, the teacher relied on strategies in learning activities and it was found out that no special media used in teaching Akidah Akhlak subjects and it can be said that the system learning lacks one component that can affect other components in improving the quality of learning.

2. Information Collection, the information was collected by the researcher to assist the process of developing the Akidah Akhlak comics can run systematically. The data were in the form of a book package of Akidah Akhlak for the seventh grade students and the syllabus of Akidah Akhlak for the seventh grade in semester 1 and 2 in the 2013 curriculum. Besides, it was found out that the school prohibited the students to bring a handphone for learning activity at school. After conducting observation, several images or stories were found in the students' book. It was used to stimulate student curiosity; this makes researcher interested in developing it into a learning medium without having to change the pictures or stories contained in the textbook. After the data or information were collected, the researchers planned the development of learning media on the Akidah Akhlak subject in the form of comics.

3. Product Design. At this stage, the developed Akidah Akhlak comics that had been planned were designed. The stages were conducted to design the Akidah Akhlak comics, namely: First, Material Selection, in this study the material was chosen by the researcher in chapter 1 in odd semester entitled "Akidah Islam". This material was chosen because it adjusted to the student's needs after conducting the test. Besides this material was suitable if a learning media was made to overcome the limitations of the learning experience that cannot be obtained directly. Second, determining the theme, the theme in the comics was adjusted to the material "Like a Tree", this theme focused on the discussion. This theme was taken because it was based on the main idea of what was to be conveyed in this comic. Third, determining the flow, as for the type of storyline used in the Akidah Akhlak comic was a mixed plot or flow back and forth. The story started from the middle without telling the background of the incident at first. Fourth, determining the characters in line with theme, the characters used in the development of the Akidah Akhlak comic media were the main characters of three children who were friends (Three Friends) since childhood and they have different backgrounds in life. In each of their daily lives, sometimes they found religious problems that were resolved by themselves or other parties help them. The introduction of these 3 main characters would be presented in one part of the comic itself later. Fifth, determining the scenario, at the time of making the scenario by arranging the dialogue that had been selected as the discussion in the dialogue. A dialogue was made with the panel by determining the setting of the place and time. Sixth, the drawing process, the steps of drawing done by the researcher, namely a) Preparing tools for drawing such as paper, pencil, eraser, ruler, liquid pen, and other needed things, b) Sketching a picture on the panel that had been made by paying attention to the size of the image so there was still room to make the conversation balloon, c) thickened the sketch line and gave color until the picture became clearer, shown in figure 2, d) scanning the image that had been explained, changed it in JPEG format, e) the researcher used Microsoft Office Word 2007 software for adding the speech balloons since its easy usage, which was indicated in Figure 3, and stage f) arrange the picture into a complete comic followed by making the front cover, preface, reading instructions, and others. When it was finished, the comic was ready to be printed. 


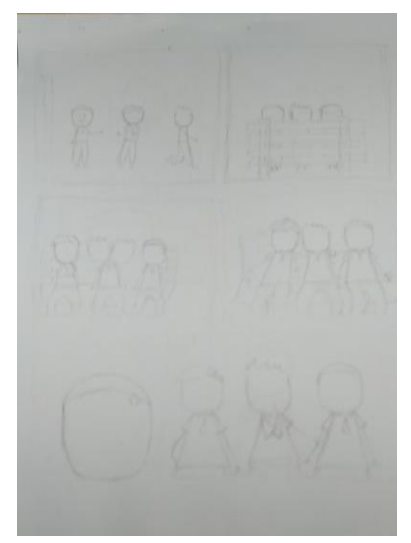

Sketch

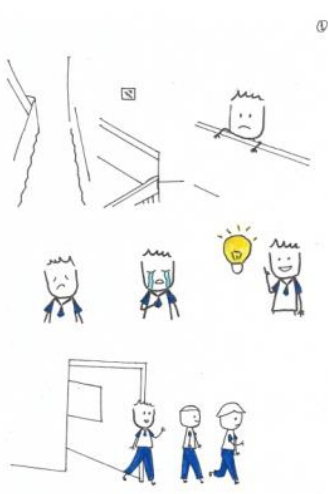

The result of bolding the line

Figure 2

Langkah sketsa gambar

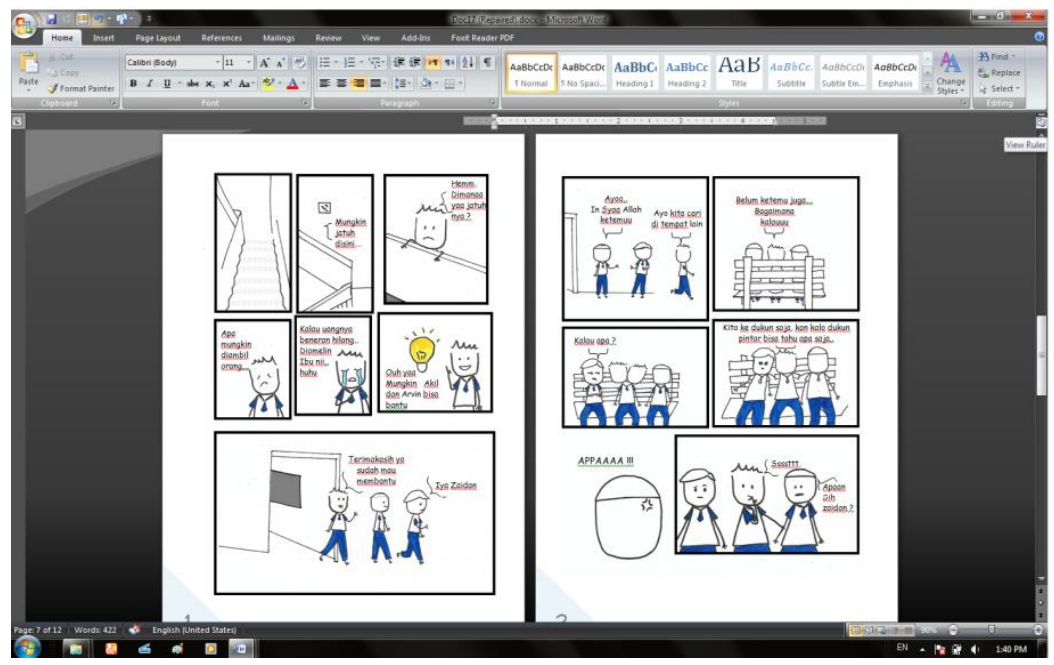

Figure 3

The Result of Editing in Microsoft Office Word 2007

4. Validasi Desain, Sebelum produk yang berupa komik Akidah Akhlak ini diujicobakan, diperlukan adanya validasi yang merupakan kegiatan mengumpulkan data atau informasi dari para ahli dibidangnya yang bertujuan untuk mengetahui tingkat kelayakan media komik Akidah Akhlak ini juga menentukan valid atau tidak valid media yang dikembangkan. Hasil dari validasi yang berupa masukan digunakana untuk perbaikan media komik pada mata pelajaran Akidah Akhlak.

Validasi terhadap produk dilakukan oleh 2 orang validator terdiri dari ahli media dan ahli materi yaitu dosen STAIN Gajah Putih Takengon juga 1 orang ahli praktisi yaitu guru mata pelajaran Akidah Akhlak di MTs Negeri 1 Takengon kelas VII. Data diperoleh dari angket penilaian yang telah diisi oleh validator dan ahli praktisi, selain memberikan penilaian, validator juga memberikan kritik dan saran terhadap produk pengembangan pada bagian akhir angket. Adapun data hasil validasi terhadap produk pengembangan media komik Akidah Akhlak sebagai berikut: Dengan hasil presentase yang sudah didapatkan dan kemudian dicocokkan dengan tabel konversi tingkat pencapaian sehingga produk pengembangan berupa komik dikategorikan "Sangat layak"dengan nilai yang didapat antara $81 \%-100 \%$. Hal ini dapat dikatakan bahwa komik yang dihasilkan layak digunakan dikelas dalam pembelajaran, walaupun masih ada yang harus diperbaiki/direvisi. Ahli materi pada proses pengembangan media pembelajaran komik merupakan ahli yang kompeten dibidangnya.

4. Design Validation, before the product in the form of Akidah Akhlak comic was tried out, validation was required, which was an activity to collect data or information from experts in their fields that aimed to determine the feasibility of the media of Akidah Akhlak comics and the validity or invalidity of developed 
media. The results of the validation in the form of input were used to improve the comic media of Akidah Akhlak subject.

The validation of the product was done by two validators consisting of media experts and material experts, namely: the lecturer of STAIN Gajah Putih Takengon and also one practitioner expert, namely the subject of the Akidah Akhlak in the seventh grade in MTs Negeri 1 Takengon grade. Data were obtained from the assessment questionnaire that had been filled out by the validator and expert practitioners, in addition to providing an assessment, the validator also provided criticism and suggestions for product development at the end of the questionnaire. The result of the product development of the Akidah Akhlak comic media as follows. The obtained results were matched with the conversion table of achievement level so that the development of comic products was categorized as "Very feasible" with obtained values between $81 \%$ $100 \%$. It can be said that the comics are suitable for learning, although there are still things that need to be improved/revised. Material experts in the process of developing comic learning media are competent experts in their fields.

5. Design revision, after conducting a validation, there were several things needed to be revised from Akidah Akhlak, namely the changes in the use of images referred to more tolerant one, this revision was submitted by expert validators with the reason that the use of images related to the shirk could lead to misunderstandings for who feel related to the image. The revision can be seen in the following Figure 4, before the revision, it displayed a picture of the statue, but after the revision based on consideration so that the picture was replaced to avoid misunderstanding.

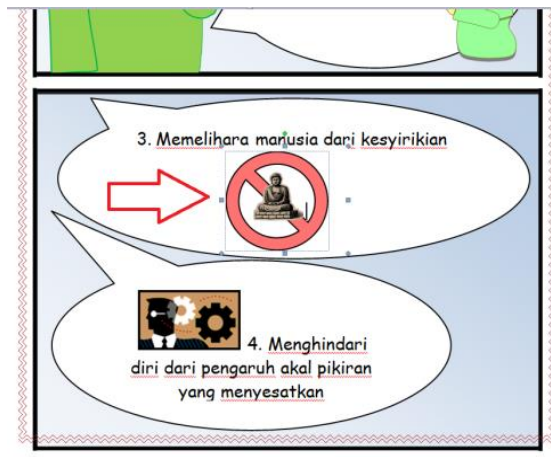

Before revision

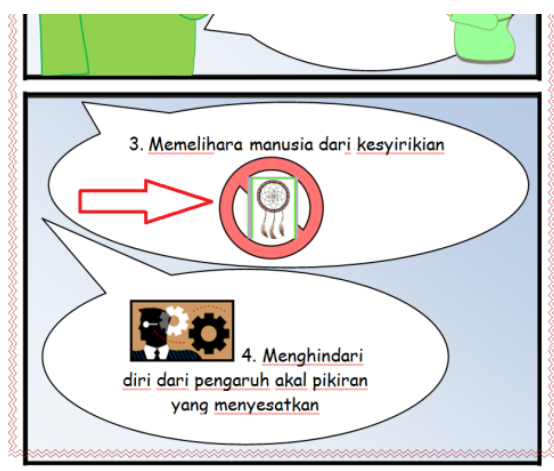

After revision

Figure 4

The Revision of Comic Display Conducted by Validators

The selection of Dream Catcher was used to substitute an image related to shirk due to an amulet is a form of shirk, as the name, a hanger means "dream catcher" is considered as a talisman that will keep people from nightmares while sleeping.

6. Small group testing was conducted on the seventh grade students of MTs Negeri 1 Takengon with a total of 10 students. The selection of students as respondent trials was done with a simple random sampling technique or random selection to provide equal opportunities for students to be selected as respondents. Based on the results of small group trials, it obtained the assessment results of 10 respondents toward the application of comic media in Akidah Akhlak subjects. Eight of ten respondents gave very good assessment as a learning medium, and 2 other respondents gave a good assessment as a learning medium. Based on the results of the overall trial, the number of suspensions was 438 with a maximum score of 500 , then a percentage of $87.6 \%$ was obtained and it can be concluded that the Akidah Akhlak comic media is very good to be used as a learning medium.

7. Product Revision, after product trials were conducted at MTs Negeri 1 Takengon including 10 respondents of the seventh grade student and teacher of Akidah Akhlak subject, the positive responses and results without any revisions were obtained.

8. Mass Production, the mass production of the researcher was done by delivering the Akidah Akhlak comics to similar schools with MTs 1 Takengon which was located around the Takengon city, namely MTs Negeri 2 Takengon. Products can be accessed through the following link: https://drive.google.com/file/d/1ONrMF3PpswEHsgeMV9MqvePQw8glzMAL/view?usp=drivesdk.

\section{Discussion}

Based on the explanation above, it can be seen that the comic media of Akidah Akhlak subject on Akidah Islam entitled "The Comrades of Three Friends" can be used for learning Akidah Akhlak. The Akidah 
Akhlak comic media was developed using the Borg \& Gall model consisting of 10 stages, but in this study was limited to 8 stages because the seventh stage has reached a feasible category to proceed to the tenth stage, namely mass production, which means stages 8 and 9 such as a trial of product usage and revision was not conducted. It is similar to a study conducted by Masykur, which did conduct all 10 stages of development (Masykur, Nofrizal, \& Syazali, 2017). In addition, the $8^{\text {th }}$ stage was not conducted because product effectiveness was not examined. Nugroho also restricted the research steps to only 8 stages, it was because the results of the first product trial were very good (Nugroho, Putra, Putra, \& Syazali, 2017).

Before the Akidah Akhlak comic was made, the researcher collected information and identified problems in MTs Negeri 1 Takengon. Based on observations, it was found that MTs 1 Takengon had used the 2013 Curriculum in learning, meanwhile, it did not have a special media for the subjects of Akidah Akhlak, a learning process relied solely on strategy, pictures, or stories were used to stimulate student curiosity on the package book. Based on these observations, researcher see that there is potential that can be developed, namely the Akidah Akhlak comic media. After the researchers found the potential and the existing problems, the researchers collected data to simplify the process of further development of the obtained data in the form of teaching materials used in the form of textbooks and syllabus in learning Akidah Akhlak.

After the second stage was completed, a general overview was obtained regarding the development of the Akidah Akhlak comic media. The researcher decided the material by considering student needs during testing the product. Next, the theme, plot, and character of the story were determined to create a dialogue of the story. After making the dialogue, the drawing process was done manually and the image was edited using Microsoft Office Word 2007. After the Akidah Akhlak comic was finished and printed, then it went to the next stage, namely the material validation conducted by experts which got $81 \%$ with very decent criteria without revision. Furthermore, the media validation conducted by experts showed $94.2 \%$ with very decent criteria with revisions to the images related to shirk. Based on the validation results, the next stage of product revision was conducted, namely revising based on the validator's suggestions.

The next stage was the product trial that conducted on the seventh grade students and teacher of Akidah Akhlak subject. A small group test in the seventh grade students as respondents was conducted on 10 students who were given a comic book of Akidah Akhlak and the Questionnaire. The average results found after conducting trials on 10 respondents were $87.6 \%$ and it can be concluded that the Akidah Akhlak Comics media is practically used as a learning medium for the Akidah Akhlak. In the trial of the seventh grade teachers by giving Akidah Akhlak Comics as well as an evaluation questionnaire on the comics, the score was $97 \%$ with very decent criteria that it can be concluded that the Akidah Akhlak comics can be used at school. From the obtained results, in general, this media no longer needs to be revised. The research product in the form of learning media comics has different characteristics from other comics, it is the same as the development of comic media conducted by (Fahyumi, 2016), on the comic development on Akidah Akhlak.

The final stage of developing this comic media was mass production. By distributing the book of Akidah Akhlak Comics to similar schools with MTs Negeri 1 Takengon, namely MTs Negeri 2 Takengon and MTs Negeri 3 Pegasing. The success of this research in developing comic learning media, along with research conducted by Novianti who developed comic media to understand the story, this research has similarities with akidah Akhlak that uses a lot of stories in the material (Novianti \& Syaichudin, 2010). Research on comic development was also conducted by Lestariningsih, the comic media was also suitable for learning (Lestariningsih \& Suardiman, 2017). From some comparisons, it can be concluded that comic learning media is suitable for learning.

\section{Conclusion and Suggestion}

Based on the results of this research and development, it can be concluded that this research and development produces a product in the form of a comic-based learning media in the Akidah Akhlak subjects of in the seventh grade Islamic material in MTs Negeri 1 Takengon. The stages are carried out using a modification and development model of Borg \& Gall consisting of 10 steps but only 8 steps are conducted, namely: problem identification, information collection, product design, design validation, product revision, product testing, product revision, and mass production. The other two steps are not carried out because the values/results had been achieved. Based on the validation of material experts and media experts, it can be seen that the validation results of material experts around $81 \%$ or very feasible and the validation results of media experts around $94.2 \%$ or very feasible. The trial results of the seventh grade teacher of Akidah Akhlak subject as expert practitioners obtain a percentage value of $97 \%$ or very feasible and $87.6 \%$ or very good is obtained from 10 respondents. Overall, it shows that comic media are very suitable to be used as learning media. Based on the research that has been done, several suggestions can be conveyed, namely: (1) for teachers, comic-based learning media can be used on Akidah Akhlak Subject of Akidah Islam Material, (2) for the principal, it is expected to facilitate other 
teachers in developing similar learning media, (3) for other researchers who have similar studies, it can be used as a reference or continue this research at a later stage.

\section{References}

Abdul Majid.2013. Strategi Pembelajaran. Remaja Rosdakarya: Bandung.

Arsyad, A. (2011). Media Pembelajaran. Jakarta: PT Raja Grafindo Persada.

Daryanto. (2016). Media Pembelajaran. Yogyakarta: Gava Media.

Emzir. (2013). Metodologi Penelitian Pendidikan Kuantitatif dan Kualitatif. Jakarta: Rajawali Press.

Eni Fariyatul, Imam Fauji, F. (2017). Pengembangan Komik Akidah Akhlak untuk Meningkatkan Minat Baca dan Prestasi Belajar Siswa Sekolah Dasar. Jhalaqa: Islamic Education, 1(1), 17-26. https://doi.org/http://doi.org/10.21070/halaqa.v1i1.817

fahyumi, E. fariyatul. (2016). Development of Aqidah-Morals Comic To Increase Reading Interest and Student Results Fourth Grade Primary School. Educational Technology World Conference (ETWC).

Hidayah, Nurul dan Rifky Khumairo Ulva. (2017). Pengembangan Media Pembelajaran Berbasis Komik Pada Mata Pelajaran Ilmu Pengetahuan Sosial Kelas IV Mi Nurul Hidayah Roworejo Negerikaton Pesawaran. Jurnal Pendidikan dan Pembelajaran Dasar Volume 4 Nomor 1 Juni 2017 p-ISSN 2355-1925 e-ISSN 2580-8915. http://ejournal.radenintan.ac.id/index.php/terampil/article/download/1804/1477.

Ismi Fatimus Zahro Utariyati, S. W. dan S. Z. (2015). Pengembangan Media Pembelajaran Berbasis Komik dalam Materi Sistem Pernapasan pada Siswa Kelas VIII MTs Muhammadiyah 1 Malang. Jurnal Pendidikan Biologi Indonesia, 1(3), 343-355. https://doi.org/https://doi.org/10.22219/jpbi.v1i3.2668

Koendoro, Dwi. 2007. Yuk, Bikin Komik Sambil Ketawa. Mizan Media Utama. Bandung.

Lin, S.-F., \& Lin, H. (2016). Learning nanotechnology with texts and comics: the impacts on students of different achievement levels. International Journal of Science Education, 38(8), 1373-1391. https://doi.org/10.1080/09500693.2016.1191089

Ntobuo, N. E., Arbie, A., \& Amali, L. N. (2018). The development of gravity comic learning media based on gorontalo culture. Jurnal Pendidikan IPA Indonesia. https://doi.org/10.15294/jpii.v7i2.14344

Rohani, A. (2014). Media Intruksional Edukatif. Jakarta: Rineka Cipta.

Rusman. (2013). Belajar dan Pembelajaran Berbasis Komputer. Bandung: Alfabeta.

Sanjaya, W. (2008). Perencanaan dan Desain Sistem Pembelajaran. Jakarta: Kencana Prenadamedia Group.

Sari, F. P., Ratnaningtyas, L., Wilujeng, I., Jumadi, \& Kuswanto, H. (2019). Development of Android Comics media on Thermodynamic Experiment to Map the Science Process Skill for Senior High School. Journal of Physics: Conference Series. https://doi.org/10.1088/1742-6596/1233/1/012052

Sudjana, N. dan A. R. (2017). Media Pengajaran: Penggunaan dan Pembuatannya. Bandung: Sinar Baru Algesindo.

Sugiyono. (2015). Metode Penelitian Pendidikan (Pendekatan Kuantitatif, kualitatif, dan R\&D). Bandung: Alfabeta.

Sun, P.-C., \& Cheng, H. K. (2007). The design of instructional multimedia in e-Learning: A Media Richness Theory-based approach. Computers \& $\quad$ Education, $662-676$. https://doi.org/10.1016/j.compedu.2005.11.016

Yulian, V. N. (2018). Developing Teaching Materials Using Comic Media to Enhance Students' Mathematical Communication. IOP Conference Series: Materials Science and Engineering. https://doi.org/10.1088/1757-899X/335/1/012110 